\title{
Energy Effective Equipment for Polyextracts Producing
}

\author{
Burdo Oleg ${ }^{1}$, Gavrilov Aleksandr ${ }^{2}$, Pylypenko Evgen ${ }^{3}$, Sirotyuk Ilya ${ }^{4}$, Sereda Aleksandr \\ 1. Doctor of Technical Sciences, Professor, Head of Department of Processes, Equipment and Energy \\ Management, Odessa National Academy of Food Technologies, UKRAINE, Odesa, Kanatna st, 112, E- \\ mail: poem.onaft@gmail.com
}

2. Ph.D., Associate Professor, Department of Technologies and Equipment of Production and Processing of Livestock Products, Academy of Bioresurces and Environment "V.I. Vernadskiy CFU", UKRAINE, Simferopol, E-mail: tehfac@mail.ru

3. Engineer of the Department of Processes, Equipment and Energy Management, Odessa National Academy of Food Technologies, UKRAINE, Odesa, Kanatna st., 112, E-mail: pylypenkojack@gmail.com

4. Graduate student, Assistant of the Department of Processes, Equipment and Energy Management, Odessa National Academy of Food Technologies, UKRAINE, Odesa, Kanatna st, 112, E-mail: ilyxin09@gmail.com

5. Engineer of the Department of Processes, Equipment and Energy Management, Odessa National Academy of Food Technologies, UKRAINE, Odesa, Kanatna st., 112, E-mail: seredasasha1995@gmail.com

\begin{abstract}
The results of modeling of the polyextracts obtaining process under electromagnetic field conditions are presented. The scheme of formation of traditional diffusion and additional hydrodynamic components from solid phase of raw materials is shown. The stages of solid phase and extactant interaction under electromagnetic field conditions are considered. The principal scheme of line of the polyextracts and their concentates production is presented.
\end{abstract}

Keywords - extraction, evaporation, drying, electromagnetic field, vacum, polyextracts.

\section{Introduction}

Extraction is a key process in many chemical, pharmaceutical and food industries. This process often determines the duration of the technological cycle, energy intensity and quality of the finished product. Traditionally, the process is based on the selective interaction of a specific target component of the solid phase and extractant. To obtain complex compositions polyextracts, they use either a cascade of devices, in which the solid phase sequentially interacts with extractants of different nature, or with multiphase extractants. The search for new technical solutions in the problems of extraction is relevant.

\section{Research results}

The authors created a fundamentally new equipment for extraction. The constructions are based on the principle of volume energy supply and hypothesis realization: "with certain combinations of the structure of the raw material and electromagnetic field parameters, initiation from the capillary-porous structure of the solid phase of a powerful mechanical flow, carrying with it a complex of target components of soluble and extractable extractant components, is possible" The devices implement a new effect, which the authors called "mechanodiffusion". If traditional extraction technologies provide only diffusional mass transfer from the solid phase, then the proposed constructions create conditions for the exit of additional vapor-liquid flows from the volume. The driving force of these flows is the pressure difference (Fig. 1). The condition for the functioning of such structures is the presence of polar molecules. 


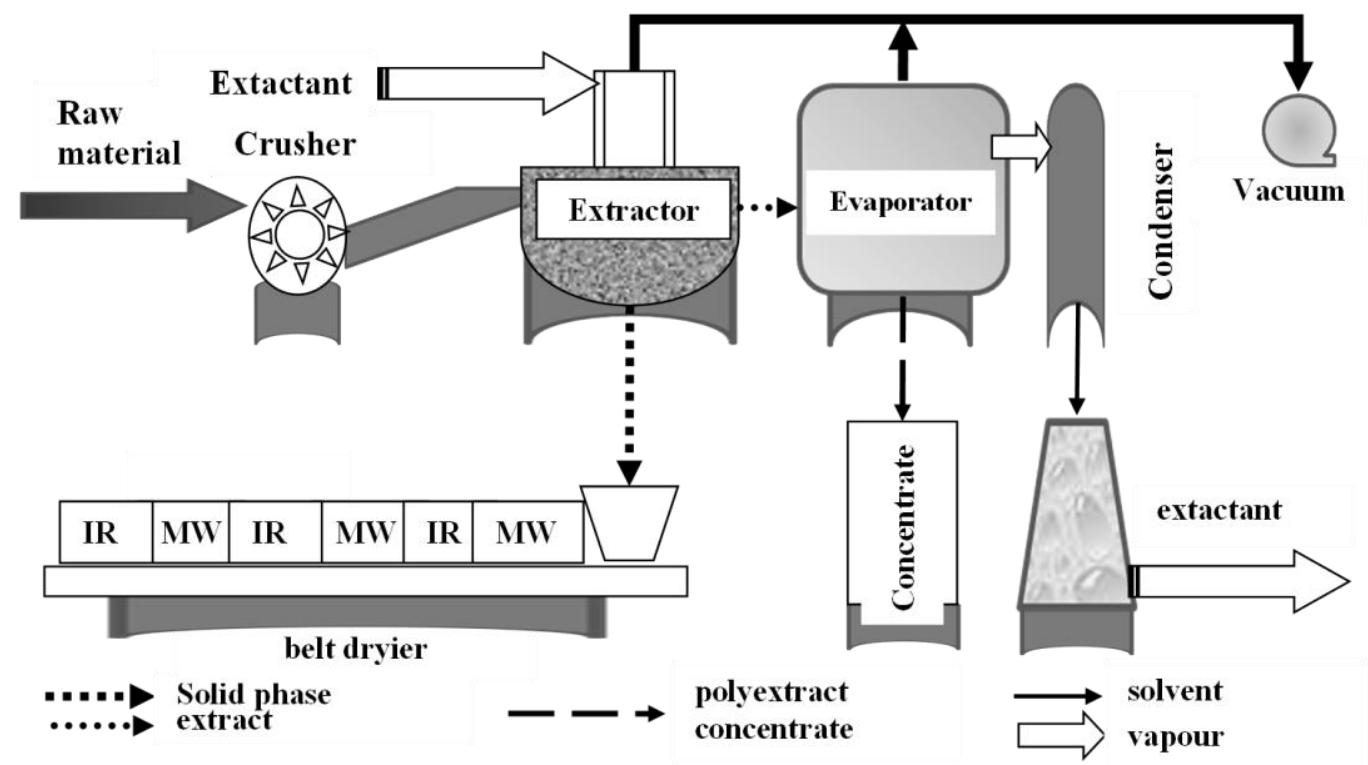

Fig.1. Raw material processing line with electrodynamic apparatus for extraction, drying and evaporation.

The raw material after preliminary machining is fed to a vacuum extractor of electrodynamic type (EDE). The sources of energy in the apparatus are microwave magnetrons. To stabilize the temperature regime during the processing of thermolabile raw materials, a refrigerator is installed in the device. At the end of the extraction process, the extract is fed to an evaporator (VMWA), and the solid phase is fed to a belt dryer bunker (BD). The solid phase on the tape moves sequentially through a cascade of cameras with microwave (MW) and infrared (IR) intensifiers. The task of MW generators is to deliver moisture from the volume of raw materials to the surface. The task of IR generators is to remove moisture from the surface.

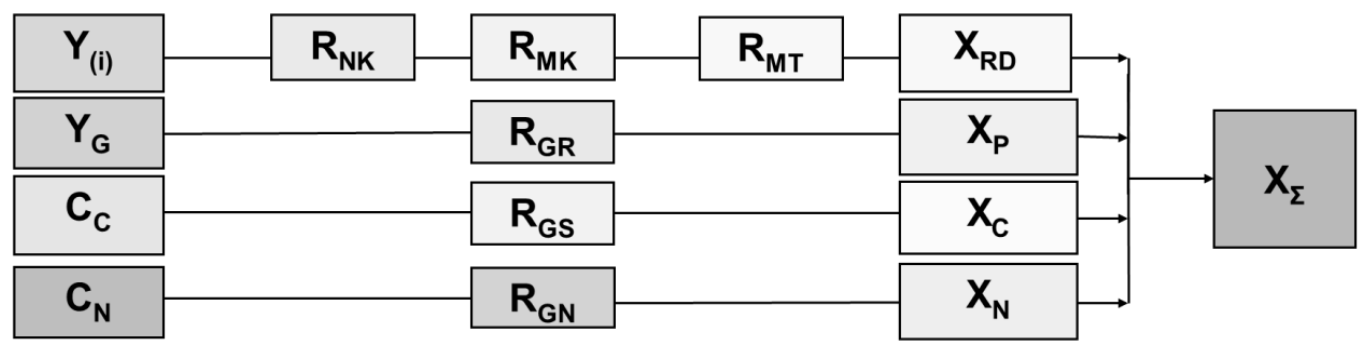

Fig.2. Equivalent electrodiffusion scheme of conjugate processes.

Here, $\mathrm{Y}(\mathrm{T})$ and $\mathrm{Y} \Gamma$ - respectively, flowing in the solid phase and the boundary value of the concentration of soluble components; $\mathrm{X} \Sigma$ - the total value of all components transferred to the extract; $\mathrm{CC}$ and $\mathrm{SN}$, respectively, concentrations in the solid phase of the poorly soluble and insoluble in the extractant components; $\mathrm{XC}$ and $\mathrm{XH}$ - the same, but in the extract. Based on the classical thermophysical mass transfer scheme [1], the diffusion transport mechanism from the fibrous structure to the flow corresponds only to the part of the circuit (fig. 2- 3). The successive chain of diffusion resistances consists of the sum: RHK (nanocapillaries), RMC (microcapillaries) and RMT (mass transfer).

The total flow of all components in the integral form is determined:

$$
\Sigma M_{I}=\left(M_{P 1}+M_{P 2}+M_{C}+M_{H}\right) F^{-1}=\frac{Y-X_{P Д}}{R_{\text {Д }}}+\rho\left[\frac{P_{K}-P_{0}}{R_{\Gamma P}}+\frac{P_{K}-P_{0}}{R_{\Gamma C}}+\frac{P_{K}-P_{0}}{R_{\Gamma H}}\right],
$$


The possible mechanisms of transport processes in the system "cell volume-shellintercellular space-environment" are presented in Table 1.

Table 1

Mechanisms and stages of the transfer processes of components from plant raw materials in the gradientless supply of electromagnetic energy

\begin{tabular}{|l|l|l|}
\hline $\begin{array}{l}\text { Raw material } \\
\text { elements }\end{array}$ & \multicolumn{1}{|c|}{$\begin{array}{c}\text { Mode and mechanism of the } \\
\text { process }\end{array}$} & \multicolumn{1}{c|}{ Processes stages } \\
\hline $\begin{array}{l}\text { Intercellular } \\
\text { space }\end{array}$ & $\begin{array}{l}\text { Mass transfer during extraction due } \\
\text { to diffusion mechanisms }\end{array}$ & $\begin{array}{l}\text { 1) Extraction of the extractant into the } \\
\text { channels; } \\
\text { 2) Diffusion of soluble substances in the } \\
\text { cramped conditions of the capillary; } \\
\text { 3) Convective diffusion from the interface } \\
\text { into the medium }\end{array}$ \\
\hline $\begin{array}{l}\text { Intercellular } \\
\text { space }\end{array}$ & $\begin{array}{l}\text { Mass transfer of soluble and } \\
\text { insoluble components from } \\
\text { channels into the medium due to } \\
\text { inertial forces }\end{array}$ & $\begin{array}{l}\text { 1) Formation of the center of vaporization; } \\
\text { 2) Growth of pressure in the channel; } \\
\text { 3) The release of components from the } \\
\text { channels into the medium }\end{array}$ \\
\hline Cell volume & $\begin{array}{l}\text { Combined energy, filtration and } \\
\text { diffusion effects on cell contents, } \\
\text { mechanical action on the cell } \\
\text { membrane }\end{array}$ & $\begin{array}{l}\text { 1) Formation of the center of vaporization; } \\
\text { 2) The growth of pressure in the cell, and } \\
\text { its volume; } \\
\text { 3) Transition of components from the cell } \\
\text { volume into the intercellular space }\end{array}$ \\
\hline Cell sheath & $\begin{array}{l}\text { Deformation of the cell membrane } \\
\text { due to internal pressure forces }\end{array}$ & $\begin{array}{l}\text { 1) Increase in the degree of stress state of } \\
\text { the cell membrane; } \\
\text { 2) Increase in the diameters of the } \\
\text { permeable channels of the membrane; } \\
\text { 3) Rupture of the membrane }\end{array}$ \\
\hline
\end{tabular}

\section{Conclusion}

The use of address energy delivery technology allows to create principal new equipment for conducting of extraction and dehydration processes. The proposed construction of extractor makes it possible to obtain multicomponental solutions and polyextracts by the one extractant. The new construction of evaporator allows to thicken extracts up to $90^{\circ} \mathrm{brix}$. The proposed belt dryier is able to get dehydrated solid phase with low energy consumption.

\section{References}

[1] O. Burdo, V. Bandura, A. Zykov, I. Zozulyak, Yu. Levtrinskaya, E. Marenchenko "Development of wave technologies to intensify heat and mass transfer processes" EasternEuropean Journal of Enterprise Technologies. Vol. 4, is. 11(88), p. 34-42, 2017.

[2] O. Burdo, I. Sirotyuk, Yu. Alhuri, Yu. Levtrinskaya, "Microwave Energy, as an Intensification Factor in the Heat-Mass Transfer and the Polydisperse Extract Formation", Problemele energeticii regionale, vol. 1, is. 36, p. 58-71, 2018. DOI: 10.5281/zenodo.1217259 